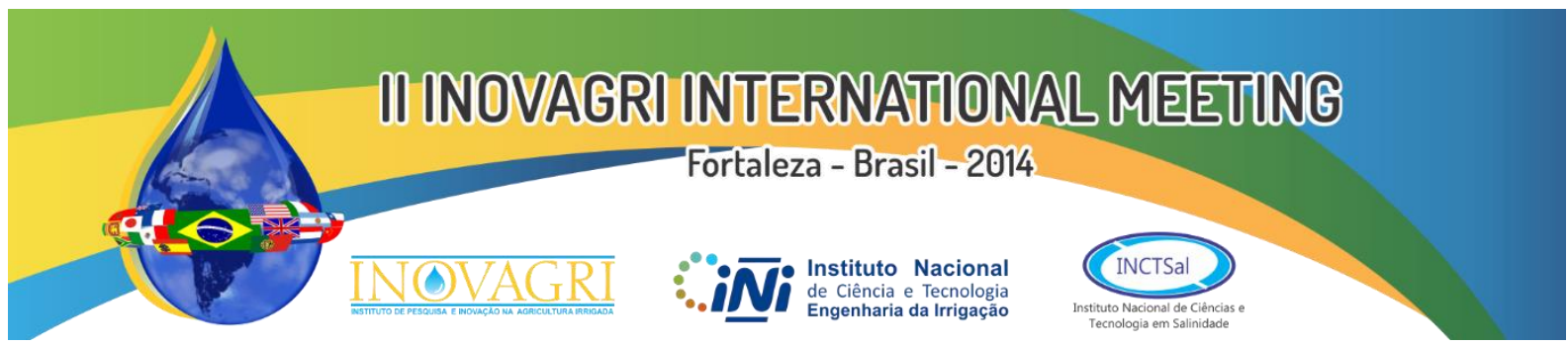

http://dx.doi.org/10.12702/ii.inovagri.2014-a099

\title{
IRRIGATION PERFORMANCE ASSESSMENTS FOR CORN CROP WITH LANDSAT IMAGES IN THE SÃO PAULO STATE, BRAZIL.
}

\author{
A. H. de C. Teixeira ${ }^{1}$, F. B. T. Hernandez ${ }^{2}$, R. G. Andrade $^{3}$, J. F. Leivas ${ }^{3}$, D. de C. Victoria ${ }^{3}$, E. L. \\ Bolfe $^{3}$
}

\begin{abstract}
Evapotranspiration (ET) and crop coefficient (Kc) were modelled in a commercial farm with corn crop irrigated by central pivots for grain and silage in the north-western side of São Paulo State, Brazil. For ET acquirements, the SAFER (Simple Algorithm For Evapotranspiration Retrieving) algorithm was applied with Landsat satellite images during growing seasons (GS) from March to August of 2010. Polynomial functions relating crop coefficient $(\mathrm{Kc})$ and the accumulated degree-days $\left(\mathrm{DD}_{\mathrm{ac}}\right)$ allowed the estimation of evapotranspiration under potential conditions (ETp). Adding data on reference evapotranspiration (ET0), precipitation $(\mathrm{P})$, irrigation $(\mathrm{I})$ and productivity $\left(\mathrm{Y}_{\mathrm{p}}\right)$, irrigation performances were assessed. The Relative Evapotranspiration $\left(\mathrm{R}_{\mathrm{ET}}\right)$ ranged from 0.78 to 1.00 and the Water Deficit (WD) presented a maximum $110 \mathrm{~mm} \mathrm{GS}^{-1}$. The Relative Water Supply ( $\mathrm{R}_{\mathrm{WS}}$ ) with values from 1.1 to 1.4 indicated high drainage rates. The physical values of water productivity, based on ET ( $\mathrm{WP}_{\mathrm{ET}}$ ) ranged from 1.4 to $2.8 \mathrm{~kg} \mathrm{~m}^{-3}$ for grains and between 8.8 and $14.1 \mathrm{~kg} \mathrm{~m}^{-3}$ for silage, with the corresponding monetary values for grains from 0.34 to U\$ $0.68 \mathrm{US} \$ \mathrm{~m}^{-3}$, showing high return when comparing with other annual crops.
\end{abstract}

KEYWORDS: Remote sensing, evapotranspiration, crop coefficient.

\section{ACESSO AO DESEMPENHO DE IRRIGAÇÃO DA CULTURA DO MILHO COM IMAGENS LANDSAT NO ESTADO DE SÃO PAULO, BRASIL.}

RESUMO: A evapotranspiração (ET) e coeficiente de cultura (Kc) foram modelados em uma fazenda comercial com a cultura do milho irrigada por pivôs centrais para grãos e silagem, no lado noroeste do Estado de São Paulo, Brasil. Para obtenção da ET, o algoritmo SAFER (Simple Algorithm For Evapotranspiration Retrieving) foi aplicado em imagens do satélite Landsat durante os ciclos produtivos (CP) de março a agosto de 2010. Funções polinomiais relacionando o coeficiente de cultura (Kc) com os graus-dias acumulados $\left(\mathrm{GD}_{\mathrm{ac}}\right)$ permitiram a estimativa da evapotranspiração em condições potenciais (ETp). Adicionando dados de evapotranspiração de referência (ET0), precipitação (P), irrigação (I) e produtividade $\left(\mathrm{Y}_{\mathrm{p}}\right)$, os desempenhos de irrigação foram analisados. A Evapotranspiração Relativa $\left(\mathrm{R}_{\mathrm{ET}}\right)$ ficou entre 0,78 e 1,00 enquanto que a Deficiência Hídrica (WD) apresentou um máximo de $110 \mathrm{~mm} \mathrm{CP}$. O Suprimento de Água Relativo (RWS) com valores de 1,1 a 1,4 evidenciou altas taxas de drenagem. Os

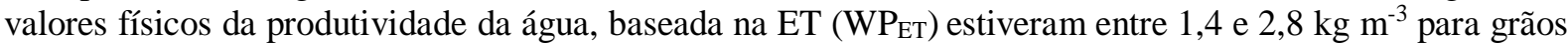
e 8,8 e $14,1 \mathrm{~kg} \mathrm{~m}^{-3}$ para silagem, com os valores monetários correspondentes para grãos de 0,34 a 0,68 US\$ $\mathrm{m}^{-3}$, apresentando elevado retorno quando comparados com outras culturas anuais.

PALAVRAS-CHAVE: Sensoriamento remoto, evapotranspiração, coeficiente de cultura.

${ }^{1}$ Ph.D., Embrapa Satellite Monitoring, 13070-115, Campinas, SP. Phone $55 \quad 1932116200 . \quad$ e-mail: heriberto.teixeira@embrapa.br

${ }^{2}$ Professor, Hydrological and Irrigation Division, UNESP, Ilha Solteira, SP.

${ }^{3}$ Doctor, Geosciences Department, Embrapa Satellite Monitoring, Campinas, SP.

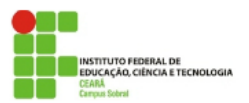




\section{INTRODUCTION}

In the Southeast region of Brazil, one of the main crops is corn (Zea mays L.), which has been cultivated in two periods of the year for human consumption or animal feed. Considering the first period (first harvest crop), the sown time is between October and November, coinciding with the start of rains, while for the second period (second harvest crop), the growing season starts in February or March.

Soil moisture is important for maintaining yield at optimum levels, being the natural water deficit (WD) the main risky factor for the second harvest corn crop, which can be attenuated at high altitudes (Ko e Piccinni, 2009). Water stress can affect the plant development and the physiological processes, reducing yield, which in turn is a linear function of evapotranspiration (Traore et al., 2000; Payero et al., 2006), both parameters used for irrigation performance assessments. For these assessments, it is important to make distinctions between reference evapotranspiration (ET0), potential evapotranspiration (ETp) and actual evapotranspiration (ET). ET0 is the evapotranspiration rate from a reference surface. $\mathrm{ET}_{\mathrm{p}}$ may be referred as the water flux from crops that growing in large fields under optimum soil moisture, excellent management and environmental conditions, achieving full production under the given climatic conditions. ET involves all situations of the vegetated surface (Allen et al., 1998).

Irrigation performance in agriculture must be efficient for food supply to the population in constant development, being important for the rational water resources management (Bos et al., 2005). Contributions from remote sensing by satellite images give opportunities for evaluating this performance at different spatial and temporal scales (Teixeira et al., 2009; Teixeira, 2010; Teixeira et al., 2013a,b). The use of satellite images for diagnostic study on irrigation performance was already carried out in a Brazilian irrigation scheme by using the visible, near-infrared and thermal bands of NOAA images (Bastiaanssen et al., 2001). However, the spatial resolution of these images is $1.1 \mathrm{~km}$ implying that many pixels cover a mixture of land use. The authors used SEBAL (Surface Energy Balance Algorithm for Land) for ET acquirements (Bastiaanssen, 2000) and the empirical Pestley and Taylor equation (Priestly and Taylor, 1972) to derive ETp.

Keeping in mind that corn crop and its production areas in the south-eastern region of Brazil are inside of the priorities from the National Ministry of Agriculture, the irrigation performance assessments in commercial farms for grain and silage are relevant, especially in the north-western side of São Paulo State. Hernandez et al. (2003) reported high probabilities of natural water scarcity for crop growing, making irrigation an essential practice for agricultural development. For the current study, due to its applicability, the SAFER (Simple Algorithm For Evapotranspiration Retrieving) model (Teixeira et al., 2013a,b) was used to estimate ET, while to take into account ETp, specific relations for grains and silage between crop coefficients $(\mathrm{Kc})$ and the accumulated degree-days $\left(\mathrm{DD}_{\mathrm{ac}}\right)$ were elaborated.

The main goal of the current research was to assess the irrigation performance of corn crop irrigated by central pivots for grains and silage in the commercial Bonança farm, located at the northwestern side of the Brazilian São Paulo State, as a subsidize for the rational water management, also generating criteria for up-scaling water variables to other ecological regions. Data on irrigation, precipitation and yield were used together with the SAFER algorithm applied to Landast images.

\section{MATERIAL AND METHODS}

Figure 1 shows the locations of the irrigation central pivots at the Bonança farm and the agrometeorological station used in the north-western side of São Paulo state, Brazil. This area is characterized by dry winter and a moderate and wet summer, presenting the highest evapotranspiration rates of the State. Some periods with absence of rains may limit the productivity without irrigation due to the natural water deficits, which can occur at durations as long as eight months (Santos et al., 2010).

The SAFER algorithm was applied to Landsat 5 satellite images from March 22, April 07, April 23, June 10, June 26, July 12 and August 29 for 2010. For ET acquirements, only the visible and near infrared bands were used together with agrometeorological data, being the surface temperature $\left(\mathrm{T}_{0}\right)$ estimated from the long-wave emitted radiation as a residual in the radiation balance. Weather data for 2010 were used together with these images and successive interpolations were performed to cover the 
complete corn crop growing seasons at each central pivot. For modelling Kc, six pivots for grains and eight for silage were considered; further selecting five of both for irrigation performance analyses.

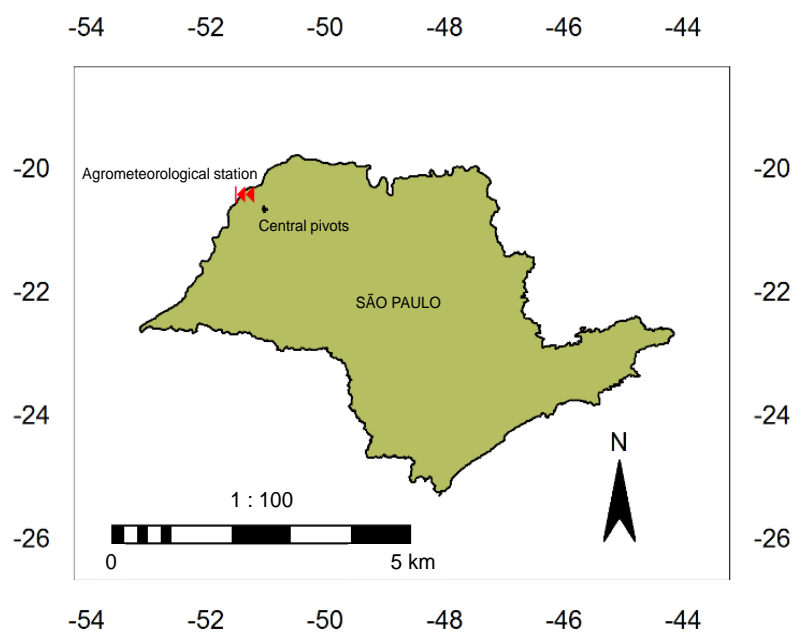

Figure 1 - Location of the irrigation central pivots over corn crop at the Bonança farm, together with the agrometeorological station used in the north-western side of São Paulo State, Brazil.

The daily values of surface albedo $\left(\alpha_{0}\right)$ were calculated according to Teixeira (2010):

$$
\alpha_{0}=a \alpha_{p}+b
$$

where $\alpha_{\mathrm{p}}$ is the planetary albedo and a and $\mathrm{b}$ are regression coefficients, which for a 24 hour period were respectively 1.70 e 0.13 .

Aiming to improve the spatial resolution in the current research, instead of using the thermal band from Landsat $5(120 \mathrm{~m}), \mathrm{T}_{0}$ in the current study was estimated with only the visible and infrared bands (resolution of $30 \mathrm{~m}$ ) as a residual in the radiation balance equation:

$$
\mathrm{R}_{\mathrm{n}}=\mathrm{RS} \downarrow-\alpha_{0} \mathrm{RS} \downarrow-\varepsilon_{0} \sigma \mathrm{T}_{0}^{4}+\varepsilon_{\mathrm{a}} \sigma \mathrm{T}_{\mathrm{a}}^{4}
$$

where RS $\downarrow$ and $T_{a}$ are respectively the daily values of the incident solar radiation and mean air temperature; $\mathrm{R}_{\mathrm{n}}$ is the daily net radiation; and $\varepsilon_{0}$ and $\varepsilon_{\mathrm{a}}$ are respectively the surface and atmospheric emissivities; and $\sigma$ is the Stefan-Boltzmann constant $\left(5.6710^{-8} \mathrm{~W} \mathrm{~m}^{-2} \mathrm{~K}^{-4}\right)$.

$\varepsilon_{0}$ and $\varepsilon_{\mathrm{a}}$ were calculated as following (Teixeira, 2010; Teixeira et al., 2013b):

$$
\begin{aligned}
& \varepsilon_{0}=\mathrm{a}_{0} \ln \mathrm{NDVI}+\mathrm{b}_{0} \\
& \varepsilon_{\mathrm{a}}=\mathrm{a}_{\mathrm{a}}\left(-\ln \tau_{\mathrm{s}}\right)^{\mathrm{b}_{\mathrm{a}}}
\end{aligned}
$$

where $\tau_{\mathrm{s}}$ is the short-wave transmissivity calculated as the ratio of RS $\downarrow$ to the incident solar radiation at the top of the atmospheric; and $a_{0}, b_{0}, a_{a}$ and $b_{a}$ are regression coefficients taking as $0.06,1.00,0.94$ and 0.10 according to Teixeira (2013b).

The Slob equation for acquiring the daily values of $R_{n}$, is described as:

$$
\mathrm{R}_{\mathrm{n}}=\left(1-\alpha_{0}\right) \mathrm{RS} \downarrow-\mathrm{a}_{1} \tau_{\mathrm{w}}
$$

where the regression coefficient $\mathrm{a}_{1}$ was obtained throughout its relation with $\mathrm{T}_{\mathrm{a}}$ (Teixeira, 2010; Teixeira, 2013a,b). 
The Normalized Difference Vegetation Index (NDVI) was calculated with the bands 3 and 4 of the Landsat images (Teixeira et al., 2009; Teixeira, 2010; Teixeira et al., 2013b):

$$
\mathrm{NDVI}=\frac{\alpha_{\mathrm{p}_{(4)}}-\alpha_{\mathrm{p}_{(3)}}}{\alpha_{\mathrm{p}_{(4)}}+\alpha_{\mathrm{p}_{(3)}}}
$$

where $\alpha_{p_{(4)}}$ and $\alpha_{p_{(3)}}$ represent the planetary albedo over ranges of wavelengths in the near infrared (band 4) and visible (band 3) regions of the solar spectrum, respectively.

Having calculated the input parameters for the SAFER algorithm, the daily ET was estimated with $\mathrm{ET}_{0}$ daily data for the same time scale:

$$
\frac{\mathrm{ET}}{\mathrm{ET} 0}=\exp \left[\mathrm{c}+\mathrm{d}\left(\frac{\mathrm{T}_{0}}{\alpha_{0} \mathrm{NDVI}}\right)\right]
$$

where $\mathrm{c}$ and $\mathrm{d}$ are regressions coefficients, which for the north-western side of São Paulo were considered 1.0 and - 0.008, respectively (Teixeira et al., 2013b).

The average values of the ET/ET0 ratio in the buffered areas of the irrigation pivots and without water deficits allowed the $\mathrm{Kc}$ modelling as a function of the accumulated degree-days $\left(\mathrm{DD}_{\mathrm{ac}}\right)$ taking the basal temperature of $10{ }^{\circ} \mathrm{C}$ and considering both commercial situations, corn for grains (subscript $\mathrm{G})$ and for silage (subscript $\mathrm{S}$ ):

$$
\mathrm{Kc}_{\mathrm{G}, \mathrm{S}}=\mathrm{a}_{\mathrm{G}, \mathrm{S}} \mathrm{DD}_{\mathrm{ac}}{ }^{2}+\mathrm{b}_{\mathrm{G}, \mathrm{S}} \mathrm{DD}_{\mathrm{ac}}+\mathrm{c}_{\mathrm{G}, \mathrm{S}}
$$

where $\mathrm{a}_{\mathrm{G}}, \mathrm{a}_{\mathrm{S}}, \mathrm{b}_{\mathrm{G}}, \mathrm{b}_{\mathrm{S}}, \mathrm{c}_{\mathrm{G}}$ and $\mathrm{c}_{\mathrm{S}}$ are the regression coefficient determined in the current research.

The values of evapotranspiration under potential conditions (ETp) for grains and silage were estimated as:

$$
\mathrm{ETp}_{\mathrm{G}, \mathrm{S}}=\mathrm{Kc}_{\mathrm{G}, \mathrm{S}} \mathrm{ET0}
$$

Following Bastiaanssen et al. (2001) and Teixeira et al. (2008) the irrigation performance indicators applied in this study were the relative evapotranspiration $\left(\mathrm{R}_{\mathrm{ET}}\right)$ relative water supply $\left(\mathrm{R}_{\mathrm{Ws}}\right)$, water deficit (WD) and water productivity based on evapotranspiratiuon $\left(\mathrm{WP}_{\mathrm{ET}}\right)$ and irrigation $\left(\mathrm{WP}_{\mathrm{I}}\right)$ :

$$
\begin{aligned}
& \mathrm{R}_{\mathrm{ET}}=\frac{\mathrm{ET}}{\mathrm{ETp}} \\
& \mathrm{R}_{\mathrm{WS}}=\frac{\mathrm{V}_{\mathrm{I}}+\mathrm{P}}{\mathrm{ETp}} \\
& \mathrm{WP}_{\mathrm{ET}, \mathrm{I}}=\frac{\mathrm{Y}_{\mathrm{G}, \mathrm{S}}}{\mathrm{ET}, \mathrm{I}}
\end{aligned}
$$

where $\mathrm{V}_{\mathrm{I}}$ is the water applied through irrigation, $\mathrm{P}$ is the precipitation and $\mathrm{Y}_{\mathrm{G}, \mathrm{S}}$ is the grain $(\mathrm{G})$ or silage (S) production.

With the availability of prices for grains, as economic indicator, the index used was the monetary value of grain production over ET and I (WP\$ET $)$ and $\left(\mathrm{WP} \$_{\mathrm{I}}\right)($ Bos et al., 2005; Teixeira et al. 2008). 


\section{RESULTS AND DISCUSSION}

\section{Weather drivers}

Yield and ET both depend on the atmospheric demand, soil moisture and the absorbed photosyntetically active radiation, which in turn are conditioned by solar radiation (RS $\downarrow$ ) and precipitation (P) levels. Figure 2 shows the monthly variation of RS $\downarrow$, ET0 and P through the year of 2010 at the study area.

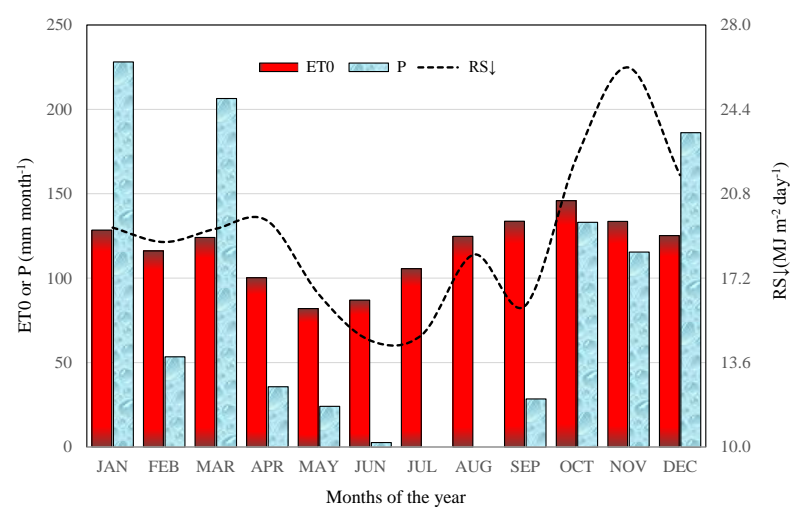

Figure 2 - Monthly total values of reference evapotranspiration (ET0) and precipitation (P), together with the monthly average $\mathrm{RS} \downarrow$ daily values at the agrometeorological station, during the year of 2010 .

$\mathrm{RS} \downarrow$ represents the main energy source for the evaporative processes. Monthly values were lower from May to September, around 16.2 $\mathrm{MJ} \mathrm{m}^{-2} \mathrm{day}^{-1}$, at the winter solstice in the South hemisphere, and higher from October to December, averaging $23.4 \mathrm{MJ} \mathrm{m}^{-2} \mathrm{day}^{-1}$, when the sun is near the zenith position with low cloud cover. Higher RS $\downarrow$ during this last period contributed to strong atmosphere demand. Although the largest ET0 values occurring at the end of the year, reaching to more than $145 \mathrm{~mm}$ month $^{-1}$ in October, the variations along the year is not so big when comparing with the corresponding ones for P. The only months with ET0 lower than $100 \mathrm{~mm} \mathrm{month}^{-1}$ were May and June. Considering the whole year, the standard deviation (SD) is relatively low, with a value of $19.6 \mathrm{~mm}$ month $^{-1}$. Considering $\mathrm{P}$ as the natural input in the water balance, much strong variation along the year were verified, with the highest values, more than $200 \mathrm{~mm} \mathrm{month}^{-1}$, happening in February and March, while July and August there was absence of rains.

Taking the difference between $\mathrm{P}$ and $\mathrm{ET}_{0}$ as a measure of water availability, in 2010 there were climatic water excesses (P > ET0) only during the months of January $(100 \mathrm{~mm})$, March $(82 \mathrm{~mm})$ and December $(61 \mathrm{~mm})$, while climatic water deficit $(\mathrm{P}-\mathrm{ET} 0<0)$ reached until $125 \mathrm{~mm} \mathrm{month}^{-1}$ from July to September. As the stages of the second harvest corn crop are concentrated from April to September, the need of irrigation is evident, which should be based on crop water requirements. One suitable way to make the rational irrigation management is throughout the crop coefficient (Kc) approach (Allen et al., 1998). Kc can be determined throughout field measurements (Teixeira et al., 2008; Teixeira, 2009); however, remote sensing by satellite images is another powerful tool for its modelling (Tasumi and Allen, 2007). Modelling the Kc values during the growing seasons is the first step and the challenge for the researchers when aiming an efficient water use. The second one is related to the extension services for disseminating the Kc use with sufficient accuracy.

\section{Crop coefficient modelling}

ET can deviate from ETp due to the presence of pests and diseases, soil salinity, low soil fertility, water shortage or water logging. This deviation from the optimum conditions affects the productivity and quality of the harvested products. The effects of characteristics that distinguish field 
crops from grass are integrated into Kc, which multiplied by ET0 gives ETp. The upper envelope of ET/ET0 values during a growing season may represent the seasonal behaviour of Kc values (Teixeira et al., 2008; Teixeira, 2009). Figure 3 shows the spatial distribution of the ET/ET0 ratio involving the Bonança farm located in the north-western part of São Paulo state, including irrigated pivot areas, natural vegetation and water.

$\mathrm{ET} / \mathrm{ET}_{0}$
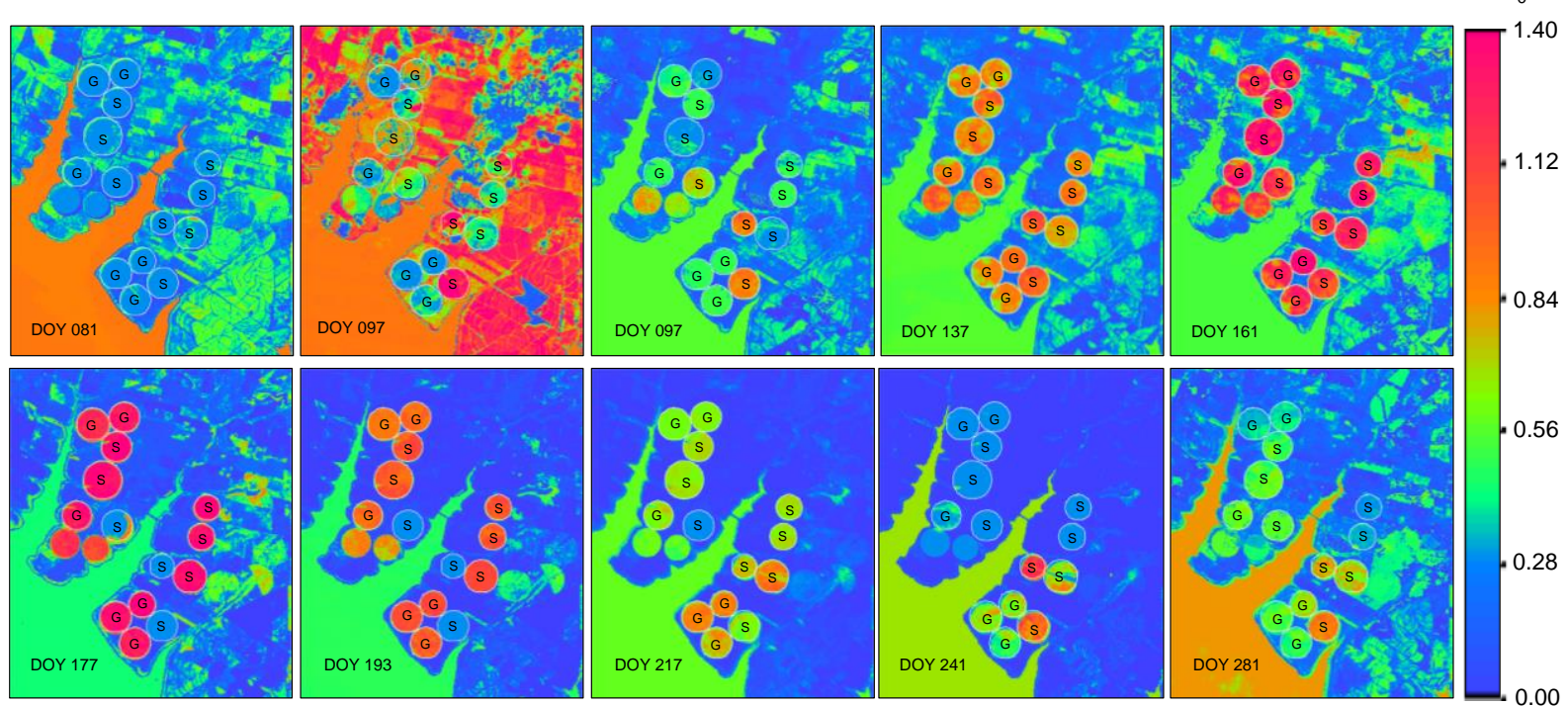

Figure 3 - Spatial distribution of the ET/ET0 ratio in the Bonança farm, located at the north-western side of São Paulo State, Brazil. DOY means Days Of the Year and the letters G and S are Grain and Silage, respectively.

Clearly one can distinguish irrigated pivots from the natural vegetation by the highest ET/ET0 values, with some pixels reaching close to 1.40. The Bonança farm has pivots with corn, soybeans and sugar cane. However, for the current study, for relate $\mathrm{K}_{\mathrm{c}}$ as a function of $\mathrm{DD}_{\mathrm{ac}}$ for corn crop, the values of ET/ET0 from SAFER results were used, considering the buffered area of six pivots of corn for grain and eight for silage, with optimum soil moisture conditions (Figure 4).
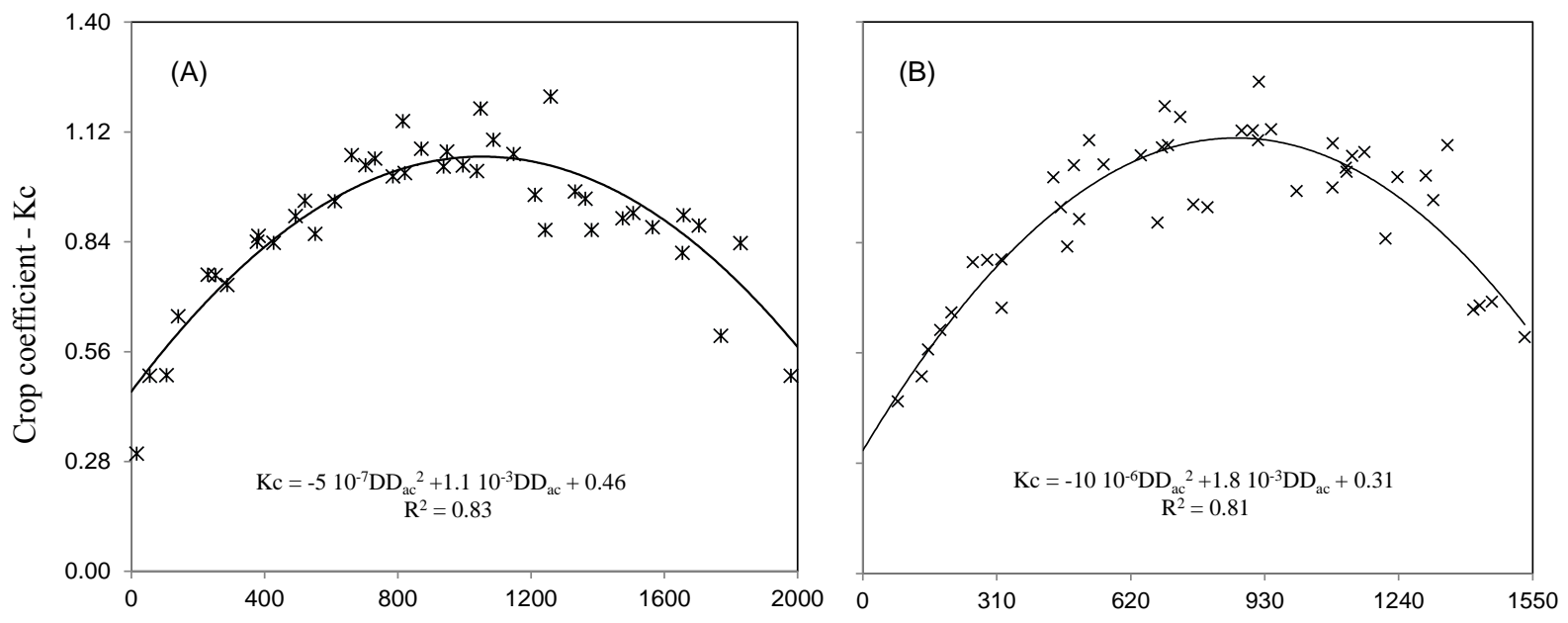

Accumulated degree-days - $\mathrm{DD}_{\mathrm{ac}}\left({ }^{\circ} \mathrm{C}\right.$ day $\left.^{-1}\right)$

Figure 4 - Relations between crop coefficients $(\mathrm{Kc})$ and the accumulated degree-days $\left(\mathrm{DD}_{\mathrm{ac}}\right)$ for corn crops. Grains (A); silage (B).

The Kc values considered as the average ET/ET0 pixels, at different corn crop stages, were between 0.3 and 1.2. This range is in agreement with the values reported by DeJonge et al. (2012) during their ET modelling improvements in Colorado (USA) and with the tabled values of the 
standard work from Allen et al. (1998). The advantage of the models showed in Figure 4 is the up scaling of the Kc values for different thermal conditions (Teixeira, 2009). In the current research, these regression equations were used to estimate ETp, which in turn, together ET, are keys parameters for the irrigation performance assessments.

\section{Irrigation performance assessments}

The instantaneous ET/ET0 ratios were also used to acquire the daily ET values with the availability of ET0 data from the agrometeorological stations. Teixeira (2010) reported no significant differences between the Landsat overpass and daily values of this ratio with field experiments involving irrigated crops and natural vegetation in the Brazilian semi-arid region. For irrigation performance assessments, ten pivots were selected in the Bonança farm, being five for grains and five for silage. Figure 5 shows the spatial variations of the ET totals for a growing season (Figure 5A) and the seasonal mean daily pixel values for each of them (Figures 5B and 5C).

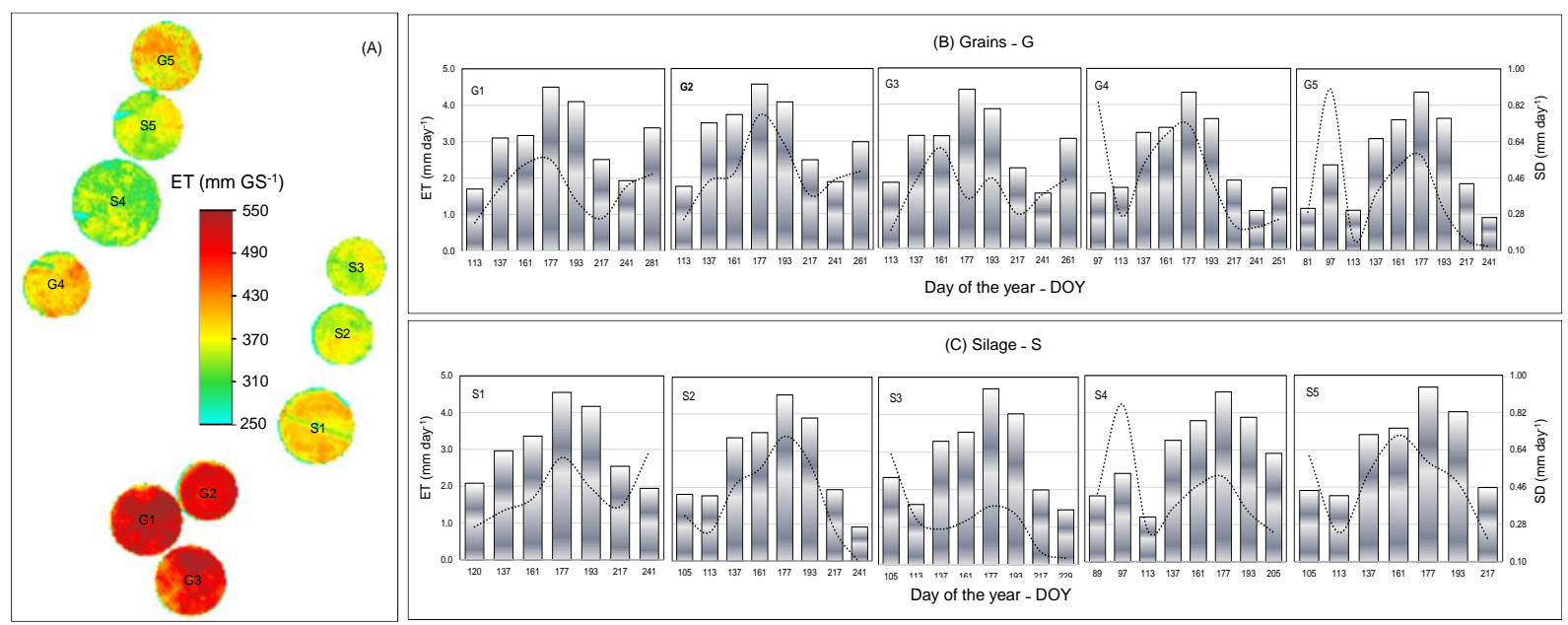

Figure 5 - Evapotranspiration for ten corn crop irrigation pivots. Spatial variation of the totals for a growing season (GS) of both, grains and silage (A); Seasonal variation of daily pixel values for grains (B) and for silage (C). G and S mean grain and silage, respectively and DOY is Day Of the Year.

For both grains and silage, the highest values are for the pivots 1, 2 and 3, however for G1, G2 and G3 several pixels above $450 \mathrm{~mm}$, while for S1, S2 and S3 most pixels presented ET GS totals bellow than $400 \mathrm{~mm}$. The highest water consumption for these pivots are due to the highest atmospheric demands involving periods ranging from DOY from 108 - 285 for grains and DOY from 105 - 241 for silage. The higher water consumption for grain than for silage, are due to the larger GS lengths, which were in average, respectively 160 and 120 days, what will affect the irrigation performance depending mainly on the rainfall conditions along the growing seasons.

According to Figures 5B and 5C the periods with the highest daily ET rates are DOY 177, grain-filling stage, while the lowest rates were verified on DOY 241, at the end of the growing seasons. The daily values were in the range from 0.9 and $4.7 \mathrm{~mm} \mathrm{day}^{-1}$ for both grains and silage. In the Northwest of China, Ding et al. (2013) throughout field measurements and modelling, found similar daily rates, around $3.5 \mathrm{~mm} \mathrm{day}{ }^{-1}$, what brings confidence for using the algorithm with the Landsat visible and infrared bands in the current research.

Knowledge of the water input and output in each pivots allowed the corn irrigation performance, including water productivity. The indicators are summarized in Table 1 for grain (A) and for silage (B). 
Table 1. Irrigation performance indicators of corn crop for grain (A) and for silage (B). Area; Growing season (GS); water applied through irrigation $\left(\mathrm{V}_{\mathrm{I}}\right)$; precipitation $(\mathrm{P})$, relative evapotranspiration $\left(\mathrm{R}_{\mathrm{ET}}\right)$; water deficit $(\mathrm{WD})$; relative water supply $\left(\mathrm{R}_{\mathrm{Ws}}\right)$; and water productivity based on evapotranspiration $\left(\mathrm{WP}_{\mathrm{ET}}\right)$ and on irrigation $\left(\mathrm{WP}_{\mathrm{I}}\right)$.

(A) Irrigation performance indicators for grain

\begin{tabular}{|c|c|c|c|c|c|c|c|c|c|c|}
\hline Pivots & $\begin{array}{c}\text { Area } \\
\text { (ha) }\end{array}$ & $\begin{array}{c}\text { GS } \\
\text { (days) }\end{array}$ & $\begin{array}{c}\mathbf{V}_{\mathrm{I}} \\
(\mathbf{m m})\end{array}$ & $\begin{array}{c}\mathbf{P} \\
(\mathrm{mm})\end{array}$ & $\begin{array}{c}\mathbf{R}_{\mathrm{ET}} \\
(-)\end{array}$ & $\begin{array}{c}\text { WD } \\
(\mathbf{m m})\end{array}$ & $\begin{array}{c}\mathbf{R}_{\mathrm{WS}} \\
(-)\end{array}$ & $\begin{array}{c}\mathbf{Y}_{p} \\
\left(t \mathbf{h a}^{-1}\right)\end{array}$ & $\begin{array}{c}\mathrm{WP}_{\mathrm{ET}} \\
\left(\mathrm{kg} \mathrm{m}^{-3}\right)\end{array}$ & $\begin{array}{c}\mathbf{W P}_{\mathrm{I}} \\
\left(\mathrm{kg} \mathrm{m}^{-3}\right)\end{array}$ \\
\hline G1 & 108.0 & 169 & 436.9 & 240.0 & 0.98 & 11.8 & 1.3 & 7.2 & 1.4 & 1.7 \\
\hline G2 & 74.0 & 155 & 498.2 & 48.0 & 0.96 & 20.0 & 1.1 & 10.3 & 2.1 & 2.1 \\
\hline G3 & 108.0 & 168 & 463.7 & 242.0 & 0.93 & 36.5 & 1.4 & 8.0 & 1.6 & 1.7 \\
\hline G4 & 91.0 & 155 & 495.6 & 65.0 & 0.78 & 110.2 & 1.1 & 8.9 & 2.3 & 1.8 \\
\hline G5 & 100.0 & 158 & 405.9 & 160.0 & 0.79 & 100.4 & 1.2 & 10.7 & 2.8 & 2.6 \\
\hline Mean & 96.2 & 161 & 460.1 & 151.0 & 0.89 & 55.8 & 1.2 & 9.0 & 2.0 & 2.0 \\
\hline
\end{tabular}

(B) Irrigation performance indicators for silage

\begin{tabular}{|c|c|c|c|c|c|c|c|c|c|c|}
\hline Pivots & $\begin{array}{c}\text { Area } \\
\text { (ha) }\end{array}$ & $\begin{array}{c}\text { GS } \\
\text { (days) }\end{array}$ & $\begin{array}{c}\mathbf{V}_{\mathrm{I}} \\
(\mathbf{m m})\end{array}$ & $\begin{array}{c}\mathbf{P} \\
(\mathbf{m m})\end{array}$ & $\begin{array}{c}\mathbf{R}_{\mathrm{ET}} \\
(-)\end{array}$ & $\begin{array}{c}\text { WD } \\
(\mathbf{m m})\end{array}$ & $\begin{array}{c}\mathbf{R}_{\mathrm{WS}} \\
(-)\end{array}$ & $\begin{array}{c}Y_{p} \\
\left(t \mathbf{h a}^{-1}\right)\end{array}$ & $\begin{array}{c}\mathbf{W P}_{\mathrm{ET}} \\
\left(\mathrm{kg} \mathrm{m}^{-3}\right)\end{array}$ & $\begin{array}{c}\mathbf{W P}_{\mathrm{I}} \\
\left(\mathrm{kg} \mathrm{m}^{-3}\right)\end{array}$ \\
\hline S1 & 118.0 & 123 & 454.9 & 57.0 & 0.99 & 2.6 & 1.3 & 33.3 & 8.8 & 7.3 \\
\hline S2 & 77.1 & 129 & 443.2 & 77.0 & 0.90 & 40.7 & 1.3 & 31.2 & 8.9 & 7.0 \\
\hline S3 & 75.0 & 124 & 442.1 & 77.0 & 0.95 & 20.5 & 1.4 & 36.5 & 10.3 & 8.3 \\
\hline S4 & 157.2 & 111 & 358.6 & 95.0 & 0.99 & 2.6 & 1.4 & 46.5 & 14.1 & 13.0 \\
\hline S5 & 100.0 & 114 & 361.8 & 52.0 & 1.00 & 0.0 & 1.2 & 48.2 & 13.8 & 13.3 \\
\hline Mean & 105.5 & 120 & 412.1 & 71.6 & 0.97 & 13.3 & 1.3 & 39.1 & 11.1 & 9.5 \\
\hline
\end{tabular}

The water indicator $\mathrm{R}_{\mathrm{ET}}$ showed a gap between the water demand and water requirements only in the pivots for grain G4 and G5, when ET was lower than $80 \%$ of ETp, with a water deficit (WD) higher than $100 \mathrm{~mm}$. In all other occasions, $\mathrm{R}_{\mathrm{ET}}$ was close to 1.00 , ranging from 0.78 to 1.00 with WD at a maximum of $110 \mathrm{~mm} \mathrm{GS}^{-1}$. $\mathrm{R}_{\mathrm{Ws}}$ with values from 1.1 to 1.4 indicated high drainage rates, due to sandy soil together with rains events. This problem happened with more intensity in the pivots for silage than those for grains. These numbers imply that in general 10 to $40 \%$ more irrigation water was supplied than necessary to meet the crop water requirements.

Taking percolation rates as the differences between P, I and ET without corrections for soil storage changes, they were in average $159.3 \mathrm{~mm}$ (35\% of ET) and $131.5 \mathrm{~mm}(37 \%$ of ET), for grains and silage, respectively. To reduce these drainages to the water table, practices of mulching should be used (Ding et al., 2013) improving water productivity. It is important to note that even with $\mathrm{R}_{\text {ws }}$ higher than 1.0 for G4 and G5 pivots, low $\mathrm{R}_{\mathrm{ET}}$ and high WD values indicated that in some occasions more water should be supplied by irrigation, as it quickly percolated away in the sand soil. Teixeira et al. (2008) reported similar gap in water requirements in a commercial mango orchard in the Brazilian semi-arid region.

Considering the pivot areas and the yield for each of than, the productivity in terms of grains ranged 7.2 to $10.7 \mathrm{t} \mathrm{ha}^{-1}$, while for silage this range was between 31.2 and $48.2 \mathrm{t} \mathrm{ha}^{-1}$. The water productivity based on evapotranspiration $\left(\mathrm{WP}_{\mathrm{ET}}\right)$ showed good return, with values from 1.4 to $2.8 \mathrm{~kg} \mathrm{~m}^{-3}$ for grains and between 8.8 and $14.1 \mathrm{~kg} \mathrm{~m}^{-3}$ for silage. The best values for grains were verified with a certain water deficit, what is an indication that water productivity increases with some degree of water stress. In average, were no significant differences when the WP was based on ET or I in the case of grain, however, for silage $\mathrm{WP}_{\mathrm{I}}$ was $86 \%$ of $\mathrm{WP}_{\mathrm{ET}}$ indicating much room for water management improvements when the corn is cultivated for silage. The main reason for this should be the use of unappropriated $\mathrm{Kc}$ for silage. $\mathrm{WP}_{\mathrm{ET}}$ values for grains are they are higher than those for wheat and rice, reported inside a range from 0.5 to $1.5 \mathrm{~kg} \mathrm{~m}^{-3}$ (Zwart and Bastiaanssen, 2004).

With the availability of prices for grains, the corresponding $\mathrm{WP}_{\mathrm{ET}}$ and $\mathrm{WP}_{\mathrm{I}}$ economic values were respectively from 0.34 to $0.68 \mathrm{US} \$ \mathrm{~m}^{-3}$ and 0.41 to $0.63 \mathrm{US} \$ \mathrm{~m}^{-3}$. On one hand, these values are much lower than for table grapes (8.1 and 2.2 US\$ $\mathrm{m}^{-3}$, respectively) and mangos (1.8 and $1.3 \mathrm{US} \$ \mathrm{~m}^{-}$ ${ }^{3}$ ) in the semi-arid region of Brazil (Teixeira et al., 2009), however, the high WP values for fruit crops occur with large production costs. On the other hand, Sakthivadivel et al. (1999) reported typical $\mathrm{W}_{\mathrm{ET}}$ values for arable crops between 0.10 and $0.20 \mathrm{US} \$ \mathrm{~m}^{-3}$, lower than those found for corn crop in the current study. Considering the importance for human and animal feed, mainly in 
rural environments, the water usage for this crop should be stimulated with sustainable irrigation managements, in areas with climatic aptitude of the São Paulo State.

\section{CONCLUSIONS}

Evapotranspiration and crop coefficients were modelled in a corn commercial farm located in the north-western side of the Brazilian São Paulo State. Landsat images with SAFER algorithm were used with only the satellite visible and infrared bands. The remote sensing parameters together with weather, irrigation, precipitation and yield data, allowed satisfactory irrigation performance assessments of irrigated pivots for grain and silage at good spatial resolution. The balance between the input and output of water indicated high drainage rates, due to sandy soil together with rains events, promoting significant percolation. However, in some occasions, more water should be supplied by irrigation, as it quickly percolated away from the corn root zones. For grains, there were no significant differences when the water productivity was based on evapotranspiration or irrigation, however, for silage, the differences indicated room for water management improvements. The main reason for this should be the use of unappropriated crop coefficient.

\section{ACKNOWLEDGEMENTS}

$\mathrm{CNPq}$ and the Brazilian Ministry of Agriculture are acknowledged for the financial support to the projects on water productivity and agrometeorological indicators, respectively.

\section{REFERENCES}

ALLEN, R.G.; PEREIRA, L.S.; RAES, D.; SMITH, M. Crop Evapotranspiration: Guidelines for Computing Crop Water Requirements; Food and Agriculture Organization of the United Nations: Rome, Italy, 1998.

BASTIAANSSSEN, W.G.M. SEBAL - based sensible and latent heat fluxes in the irrigated Gediz Basin, Turkey. Journal of Hydrology, v. 229, p. 87 - 100, 2000. http://dx.doi.org/10.1016/S00221694(99)00202-4

BASTIAANSSSEN, W.G.M.; BRITO, R.A.L.; BOS, M.G.; SOUZA, R.A.; CAVALCANTI, E.B.; BAKKER, M.M. Low cost satellite data for monthly irrigation performance monitoring: Benchmarks from Nilo Coelho, Brazil. Irrigation and Drainage Systems, v.15, p. 53 - 79, 2001. http://dx.doi.org/10.1023/A:1017967021198

BOS, M.G.; BURTON, D.J.; MOLDEN D.J. Irrigation and drainage performance assessment. Practical guidelines. CABI Publishing, Cambridge, USA, 2005, $158 \mathrm{pp}$.

DeJONGE, K.C.; ASCOUGH II, J.C.; ANDALES, A.A.; HANSEN, N.C.; GARCIA, L.A.; ARABI, M. Improving evapotranspiration simulations in the CERES-Maize model under limited irrigation. Agricultural Water Management, v. 115, p. $92 \quad$ - $103,2012$. http://dx.doi.org/10.1016/j.agwat.2012.08.013

DING, R.; KANG, S.; LI, F.; ZHANG, Y.; TONG, L. Evapotranspiration measurement and estimation using modified Priestly-Taylor model in an irrigated maize field with mulching. Agricultural and Forest Meteorology, v. 168, p. 140 -148, 2013. http://dx.doi.org/10.1016/j.agrformet.2012.08.003

HERNANDEZ. F.B.T.; SOUZA. S.A.V. de; ZOCOLER. J.L.; Frizzone. J.A. Simulação e efeito de veranicos em culturas desenvolvidas na região de Palmeira d'Oeste. Estado de São Paulo. Engenharia Agrícola, v. 23, n. 1, p. 21 - 30, 2003.

KO, J.; PICCINNI, G. Corn yield responses under crop evapotranspiration-based irrigation management. Agricultural Water Management, v. 96, p. 799 - 808, 2009. http://dx.doi.org/10.1016/j.agwat.2008.10.010

PAYERO, J.O.; MELVIN, S.R.; IRMAK, S.; TARKALSON, D. Yield response of corn to deficit irrigation in a semiarid climate. Agricultural Water Management, v. 84, p. 101-112, 2006. http://dx.doi.org/10.1016/j.agwat.2006.01.009

PRIESTLEY, C.H.B.; TAYLOR, R.J. On the assessment of surface flux and evapotranspiration using large-scale parameters. Monthly Weather Review, v. 100, p. 81 - 92, 1972. http://dx.doi.org/10.1175/1520-0493(1972)100\%3C0081:OTAOSH\%3E2.3.CO;2 
SANTOS. G.O.; HERNANDEZ. F.B.T.; ROSSETTI. J.C. Balanço hídrico como ferramenta ao planejamento agropecuário para a região de Marinópolis, noroeste do Estado de São Paulo. Revista Brasileira de Agricultura Irrigada, v. 4, n. 3, p. $142-4$ 149, 2010. http://dx.doi.org/10.7127/rbai.v4n300010

SAKTHIVADIVEL, R.; de FRAITURE, C.; MOLDEN, D.J.; PERRY, C.; KLOEZEN, W. Indicators of land and water productivity in irrigated agriculture. International Journal Water Resources Development, v. 15, p. 161-180, 1999. http://dx.doi.org/10.1080/07900629948998

TASUMI, M.; ALLEN, R.G. Satellite-based ET mapping to assess variation in ET with timing of crop development. Agricultural Water Management, v. 88, p. $54 \quad$ - $62,2007$. http://dx.doi.org/10.1016/j.agwat.2006.08.010

TEIXEIRA, A.H. de C.; BASTIAANSSEN, W.G.M.; MOURA, M.S.B.; SOARES, J.M., AHMAD, M-ud-D; BOS, M.G. Energy and Water Balance Measurements for Water Productivity Analysis in Irrigated Mango Trees, Northeast Brazil. Agricultural and Forest Meteorology, v. 148, p.1524 1537, 2008. http://dx.doi.org/10.1016/j.agrformet.2008.05.004

TEIXEIRA, A.H. de C. Water productivity assessments from field to large scale: a case study in the Brazilian semi-arid region. ed. LAP Lambert Academic Publishing: Saarbrücken, Germany, 2009, $226 \mathrm{p}$.

TEIXEIRA, A.H. de C.; BASTIAANSSEN, W.G.M.; AHMAD, M.D.; BOS, M.G. Reviewing SEBAL input parameters for assessing evapotranspiration and water productivity for the LowMiddle São Francisco River basin, Brazil Part B: Application to the large scale. Agricultural and Forest Meteorology, v. 149, p. 477 - 490, 2009. http://dx.doi.org/10.1016/j.agrformet.2008.09.014

TEIXEIRA, A. H. de C. Determining regional actual evapotranspiration of irrigated and natural vegetation in the São Francisco river basin (Brazil) using remote sensing an Penman-Monteith equation. Remote Sensing, v. 2, p. 1287-1319, 2010.

TEIXEIRA, A. H. de C.; SCHERER-WARREN, M.; HERNANDEZ, F.B.T.; ANDRADE, R.G.; LEIVAS, J.F. Large-Scale Water Productivity Assessments with MODIS Images in a Changing Semi-Arid Environment: A Brazilian Case Study. Remote Sensing, v. 5, p. 5783-5804, 2013a. http://dx.doi.org/10.3390/rs5115783

TEIXEIRA, A. H. de C.; HERNANDEZ, F. B. T.; LOPES, H. L.; SCHERER-WARREN, M.; BASSOI, L.H. A Comparative Study of Techniques for Modeling the Spatiotemporal Distribution of Heat and Moisture Fluxes in Different Agroecosystems in Brazil. In: George G. Petropoulos. (Org.). Remote Sensing of Energy Fluxes and Soil Moisture Content. 1ed.Boca Raton, Florida: CRC Group, Taylor and Francis, 2013b, v., p. 169-191.

TRAORE, S.B.; CARLSON, R.E.; PILCHER, C.D.; RICE, M.E. Bt and non-Bt maize growth and development as affected by temperature and drought stress. Agronomy Journal, v. 92, p. 10271035, 2000. http://dx.doi.org/10.2134/agronj2000.9251027x

ZWART, S.J.; BASTIAANSSEN, W.G.M. Review of measured crop water productivity values for irrigated wheat, rice, cotton and maize. Agricultural Water Management, v. 69, p. 115-153, 2004. http://dx.doi.org/10.1016/j.agwat.2004.04.007 